\title{
The Naming System for Villages and Borough in Cirebon Regency: A Study of Toponyms in Indonesia
}

\author{
Nani Darheni \\ Balai Bahasa Provinsi Jawa Barat, West Java Provincial Language Center, Indonesian
}

\begin{abstract}
This study aimes to describe "The Naming System for Villages and Borough in Cirebon Regency: A Study of Toponyms" with used descriptive-ethnographic methods Spradley (2013) and Sudaryanto (2015). Data sources are derived from some village names/borough in Cirebon District, in the form of (a) written sources (literature study) and (b) oral sources. The direction of the discussion is (1) Tracking of toponymous areas and the origin of the source/language; (2) Description of morphological constructions; and (3) Construction of toponym philosophical meanings/representations in the names of villages/borough in Cirebon District. The results of the study in the discussion are based on: (1) Source Name: Direction of winds, Water and maritime elements, Figure, Flora, and others; (2) Origin of language, namely (Javanese Cirebon, Sundanese language, Sundanese language + Javanese Cirebon, JC-Indonesian, Indonesian, Kawi language, Sanskerta, Chinese language, Javanese + Sundanese language, and Arabic; (3) Toponyms in the names of villages in Cirebon District represent meanings and philosophies related to: (a) The Relationship between man and the Creator (God Almighty), (b) HumanHuman; (c) Human-Nature; and (d) Human-the Unseen
\end{abstract}

Keywords: Toponyms, villages/borough, Cirebon District.

\section{INTRODUCTION}

$\mathrm{A}$ Study on names and naming is known as onomastics. Names are considered central in linguistic study communicated among people. Hough further explained that names in English language are categorized into nouns or noun phrases (NP) which sometimes called proper nouns (hereinafter referred to as name) (Hough, 2016). The relationship of onomastics as a linguistic branch was also asserted by Algeo in his article entitled "Is a Theory of Names Possible?" in 2010. Van Langendonck and Van de Velde (2016) also asserted that Name is noun which not only has a unique and limited denotative but also connotative meaning. Accordingly, there is the word 'toponymy' derived from Latin language, "tópos ( 'name' (Kostanski, 2009). Furthermore, the terminologies related to a toponymy study have been agreed as toponomastics in the International Congress OF Onomastic Sciences in 2011.

Toponymy is name giving topographical elements, either natural, artificial, or state administrative need element. Besides, the provision of topographical names is nationally standardized by National Names Authority (NNA) or Geospatial Information Agency (GIA). Some topographical names are packaged in the national gazetteer (list of topographical names) as mandate and recommendation from the resolution of United Nations Group of Experts on Geographical Names (UNGEGN). Island, area, river, lake, gulf naming in various areas in this country is called topography. This science is also known as geography or toponymy.

The President of the Republic of Indonesia, Joko Widodo, on 6 January 2021 has established the Government Regulation Number 2 Year 2021 on Administration of Topographical names (PP PNR). The regulation was issued to protect the territorial sovereignty and security of the Unitary State of the Republic of Indonesia, preserving the cultural values, history, and customs as well as realizing the governance administrative obedience.

Place-names can thus be seen as a cultural artefacts which arise from the interaction between language and environment. This means that to understand a place-name, when it was coined, by whom and with what motivation(s) in mind, it is important to collect as much information as possible from both side of this interaction. While the environment is studied by site-visits, conversations with local people, and through detailed maps and plans, the language is approached above all through the collection of early forms and their context, although of course conversations with local people can play an important role here too (Taylor, 2016: 70). Place-names generated by humas as language users in response to their environment. The environment is first and foremost a place in which to dwell and to sustain life, in which to pursue various kinds of recreation and ritual, and in and through which to travel. This response perforce changes over time as our relationship with our environment changes.

Lauder (2009) states that it is greatly necessary to coordinate, communicate and deliver information. This statement is based on the result on Computational Linguistics, that the frequency of emergence of personal names (anthroponymy) and place names (toponym) in newspapers is up to $33.92 \%$. This proved that name plays an important role in human life, both personal name and place name. Further, Lauder (2009) adds that toponymy is a science to learn place name (toponym), from its origin to definition, meaning, use and typology. In addition, Lauder (2013:9--13) explained that toponymy has the role in preserving the culture and formation of national identity. Thus, the role of toponymy should be directly prioritized to help the preservation of local languages and cultures. Besides, the obligation to use local languages as place names also helps form the national identity. 
In addition, Brown (1947: 66) defined language as a perfect symbol of humans' experience. Language cannot be separated from actions and is used as soft-nuance expression facility. It means that, in language, there is a framework of relationship between logical pattern and language use practice. Therefore, naming is faced to symbol system within a culture, for example the toponym on regional names in Cirebon Regency, covering village/sub-district expressed in written language, as linguistic symbol, and culture.

A morphological study is one grammatical aspect in language beside syntax (sentence structure) studies. Nida (1957: 1) explains "Morphology is the study of morphemes and their arrangement in forming words". It means morphology is science learning about morphemes and its relationship with the word formations. Kridalaksana (1996: 12) also explains that the morphological process consists of (1) zero derivation, (2) affixation, (3) reduplication, (4) abbreviation (shortened), (5) composition (pluralization), and (6) reverse derivation. One of the more are some known affix types: (a) Prefix, a bound morpheme located in front of the word stem, such as me-, di-, ber-, ke-, ter-, pe-, per-, se- (b) Infix,a bound morpheme located in the middle of phological aspects is affixation. Affixation isone lexeme formation process changed into a complex word. According to Alwi et al. (2003: 31), in Indonesian language, there a stem word, such as -el-, -er-, em-,-in-; (c) Suffix,a bound morpheme located at the end of a word stem, such as -an, -kan, -i. Accordingly, Chaer (2008: 25) explains that morphological process is a word formation process for one basic form through the addition of affix (affixation process); repetition (reduplication), incorporation (composition), abbreviation/shortened (acronymization process), and status changing (conversion process).

According to Hall (1997), language is cultural representation instrument as one of important practices in producing culture. Culture is an extensive concept and deals with sharing experience. Someone is considered from the same culture if the humans existing on the related site share the same experience, same cultural codes, speak in same language, and mutually sharing the same concept. This statement was supported by Hertley (2010: 265) explaining that representation means using language to state something meaningfully or representing language to others. Representation can be in the form of (a) word, picture, sequence, story, representing idea, emotion, fact, and others; and (b) representation depends on the culturally understood existing sign and image (in language and learning and various symbolization) or the reciprocally textual system.

Cirebon is one of the most interesting regions in Indonesia and has three center of kingdoms which are widely recognized in the history of Cirebon, namely Kasepuhan, Kanoman, and Kecerbonan Palace (Ramlan, 2008: 11). Cirebon is also a center for the development of various aspects of life, such as economy, politic, culture, history, as well as religion with various ethnics and religious backgrounds. One of the indicators of community sociocultural development in
Cirebon is the practice of naming a place (toponym). Toponym is a form of linkage between language, culture, and mindset of its people. The concept of regional toponym reflects the sociocultural and historical paradigm of its owner community. Besides thar, Cirebon is one region located in the north coast, eastern coastal area of West Java, bordering with Brebes Regency area, Central Java Province. Cirebon is a very interesting region and still has the inheritance of kingdom/Sultanate which until now is considered as center for documentation and historical evidence of Cirebon Sultanate during the Islamic syiar development period and the Golden period of Cirebon Sultanate led by Syekh Gunung Jati (Syekh Syarief Hidayatullah) in the 15th century. There are three palaces (known as Keraton) in Cirebon: Keraton Kasepuhan, Kanoman, and Kecerbonan, as explained in the previous research conducted by Darheni (2018: 570).

From its establishment historical background, Cirebon was once a region considered as a center for the spread of Islam, yet previously inhabited by the residents from various ethnic groups/tribes including Sundanese, Javanese, Chinese, Arabic, Malay, Bugis, and others. Before the establishment of Cirebon Sultanate, has become a melting pot area, where various ethnic groups/tribes, religions, and cultures met so that Cirebon had various cultures (Wahidin, 2006).

Some studies on toponymy empirically underlying this research by Salzman (1990), Ayanovna (2014), Prihadi (2015), and Camalia (2015) are as follows. Salzman (1990) studies the toponym in the form of dictions used by the society/community in Bigar Village, Banat, south of Rumania. The people of Bigar Village speak Bohemian derived Czech language. The local toponym they use may be classified into four languages, namely Czech, Serbian, Rumanian and German. Czech language is used particularly for microtoponym. More than 150 toponyms are classified and analyzed according to geographical characteristics indicated, origin, language structure and motivation. Ayanovna (2014) studies the role of Old Turkish place names in teaching history subject. She conducts a research entitled "The Role of Old Turkic Place Names in Teaching History" explaining the background of the research, that since Kazakhstan acquired its independence, it is important to reconsider the national history. Historians are demanded by the government to revise the history from old age to independence. The problem is that many modern history books flood readers with empty statistics such as dates and numbers, without significantly improving their level of substantive knowledge. In this case, history cannot be limited to presentation of empty facts of historical events, but should also give information to readers of ethnocentric world's view; it should be deemed a course, observe diachronically and show the development of ethnocentric mentality. The purpose of this qualitative research is to develop additional information systematically chosen of Turkish people's mental specificity and show its historical development by analyzing the functionalities of place names in old Turkish period. The general linguistic and scientific methods (comparative, descriptive, component 
analysis, etymological analysis) we have applied provide us: 1) understanding of mentality of ancient Turkey, world view through place name prism where they put important information; 2) overview of historic events associated with place name given. The sources (written monument OrkhonYenisei, historical, linguistic, ethnographic, geographic work and scientific literature of toponym) used are fully related to the contents of the given research. This research may be useful to the group of scientists who develop new history books and contribute to further studies of names of places of ancient Turkey (Ayanovna, 2014).

Prihadi (2015) highlights the village toponym system based on cultural aspect in Yogyakarta which is thick of palace nuance, based on the life aspects of Yogyakarta people. In this research, this area is related to the palace-centric and nonpalace-centric, which are closely related to closeness to cultural centers (palace-centric areas) and far from cultural centers (non-palace-centric) which are changing and tend to be different from the perspective of different life aspects.

Camalia (2015) studies the naming of a place with relatedness between language, culture and thought. In the research, she describes the naming of Lamongan Regency by finding the naming patterns in Lamongan Regency which reflect values and beliefs. Further, the name patterns are reflected to the place names. In addition, the research has found the marking structure in the naming formation of Lamongan Regency and found the acceptability of Sapir-Whorf Hypothesis in the toponym of Lamongan Regency. In her research, Camalia (2015) finds the relationship of Lamongan toponym with a figure named Hadi, who was a student of Sunan Giri assigned to guide and lead the people of Lamongan.

The toponymy studies in Cirebon were previously conducted by Ruspandi and Mulyadi (2014) and Anshari et al. (2017). They explained their findings in broader senses that the toponymy in Cirebon was motivated by the physical, social, and cultural aspects. The physical aspects include: a) biological elements; b) hydrological elements; and c) geomorphological elements. Social aspects include: a) specific places; b) pass activities; c) expectations; d) historical building's names; and e) character's names. The cultural aspects are contained in legends/folktales.

Toponymic studies and from the geographic aspects have been simultaneously conducted by Anshari et al., (2018). In their research, it was shown that toponymy is one onomastic branch investigating the naming on geographic elements. The number of toponym in Cirebon areas covering the administrative areas of Cirebon Regency and City is created as the result of Javanese and Sundanese cultural acculturations. Cirebon is administratively divided into city and regency with a total of 45 districts consisting of 40 districts in Cirebon Regency and five districts in Cirebon City. In Cirebon, there are 21 district toponyms containing the physical aspects, while the other 24 district toponyms containing sociocultural aspects. The meaning diversity shown by the toponyms in Cirebon includes the places' names yet not only names but also a wealth or treasure which should be well maintained and preserved by the Indonesian people.

Slightly different from previous research, In addition, a toponymy study that examined the toponymy branch in the field of waters (hydronymy) was also carried out by Stanberg (2016) and Muntele (2018)

Stanberg (2016) studies a branch of toponym, namely hydronym. In his research entitled "River Names: The Oxford Handbook of Names and Naming", he explains that Hydronym is a river naming term referring to name of flowing body of water: big river and small river, river-tributary, whitewater. This is the witness of human thoughts, activities and conditions of very remote time, naturally to the initial phase of language development (lexicon, phonology, morphology and semantic).

In line with the research conducted by Stanberg (2016)Muntele (2018) from Romania studies the history of evolution process of Moldavian population. This research proposes a spatial distribution analysis and geographic relevance of hydronym of the area. He screens the research data of 2040 water flows, identifies them in various sources of cartography and inventories additional information of the origin of the names and their meaning. The research result employs an etymological explanation of the references with which geographic relevance is consulted and categorized which are related to the elements of natural or anthropic framework. Beyond the limit applied by documentary, inherent or controversial gap in explaining the etymology and meaning of some names, the result is obtained by analyzing the statistic distribution of categories maintained which represents support of some typology classifications at the level of 32 main hydrographic basins. The research result shows a strong relationship of hydrography with distribution of some ethnic groups (now or in the past) and with natural environmental features or one caused by certain socialeconomic relationship.

Based on some research empirics, there were no data comprehensively explaining the toponym percentages related to the place names (village/sub-district) in Cirebon Regency based on the toponym sources and language origins, their linguistic forms and morphological elements as well as their philosophical meanings representing the toponym of village/sub-district names in Cirebon Regency. Therefore, the direction of the discussion is

1. Tracking of toponymous areas and the origin of the source/language;

2. Description of morphological constructions; and

3. Construction of toponym philosophical meanings/representations in the names of villages/borough in Cirebon District.

\section{METHOD}

A study on toponym related to village/sub-district names in Cirebon Regency used a descriptive method Sudaryanto 
(2015) by collaborating it with an ethnographic method Spradley (2013). This research was conducted in three phases: (1) data collection, (2) data analysis, and (3) presentation of data analysis results and discussion. For data collection, the data were collected through literature studies and directly from the field/locations. The data were collected using (1) Listening and writing technique, by (a) writing all village and sub-district names in Cirebon Regency areas, (b) having ethnographic interview, and (c) documenting the village/subdistrict name boards in Cirebon Regency. The data were then descriptively analyzed by classifying the village/sub-district names in Cirebon Regency and mapping morphologically, tracing meanings, and its philosophical values. Therefore, this research used a descriptive-qualitative method with the Spreadley's ethnographic approach (2013) explorative, listening, note-taking, taping, and documentation technique.

This research implemented the theoretical frameworks of Hough (2016)in toponym, Nida (1957) in linguisticsmorphophonology, and meaning representation Ogden \& Richards (1923) to discuss the village and sub-district names in Cirebon Regency. Meanwhile, the data sources were from the hydronyms on village and sub-district names in Cirebon Regency, in the form of (a) spoken sources (informants), consisting of speakers from cultural observers, historians, and public figures as well as (b) written sources (literature studies). The research instruments included interview, descriptive questionnaire list, structural observation sheet, and documentation..The research results were then descriptively and qualitatively presented.

The research sources and criteria based on the administrative areas of Cirebon Regency consisted of 424 village/sub-district areas from 40 districts covering 412 villages and 12 subdistricts.

\section{RESULT AND DISCUSSION}

\subsection{Research Results}

The results of toponym research on the village/sub-district names in Cirebon Regency can be classified into two criteria, namely (a) Name source and (b) Language origin, with the percentage as follows.

\section{A. Name Sources}

Based on name sources, the toponym of village/sub-district names in Cirebon Regency can be seen in the following bar chart 3.1.a.
Bar Chart 3.1.a

Frequency of Occurrence Source of Village/Borough Name in Cirebon

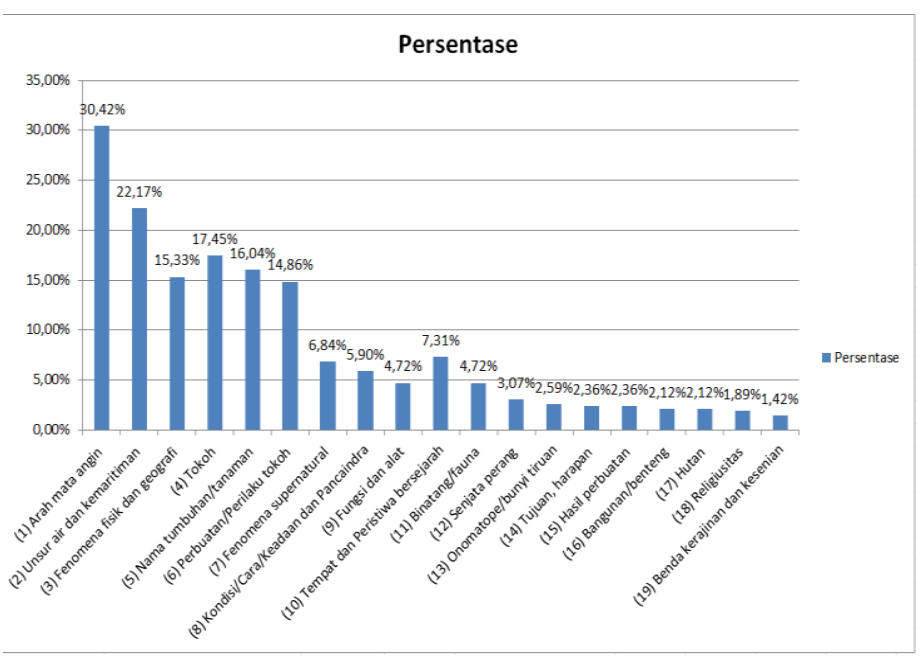

Based on the Bar Chart 3.1.a, there were 33 classifications of toponym in the village/sub-district naming in Cirebon Regency based on the naming source variations. The name sources included (1) Wind Direction (30.42\%), (2) watermaritime element (22.17\%), (3) Public Figures in the era of Sultanate Cirebon under the leadership of Sultan Gunungjati $(17,45 \%)$, (4) plant/flora names $(16.06 \%)$, (5) physical and geographical phenomena (15.33\%), (6) Public Figures' Action/behavior (14.86\%), (7) Historical places and events (7.31\%), (8) Conditions, methods, Conditions, and five senses (5.90\%), (9) Function-Equipment (4.72\%), (10) Supranatural Phenomena (6.84\%), (11) Animal/fauna (4.72\%), (12) WarWeapon (3.07\%), (13) Onomatopoeia/sound imitation (2.59\%), (14) Objective-Expectation (2.26\%), (15) Result of Action (2.36\%), (16) Building-Fort (2.12\%), (17) Forest (2.12\%), (18) Religiosity (1.89\%), and (19) art-craft object $(1.42 \%)$.

\section{Bar Chart 3.1.b}

Village/Sub-district Toponym Presence Frequency Based on Name
Sources

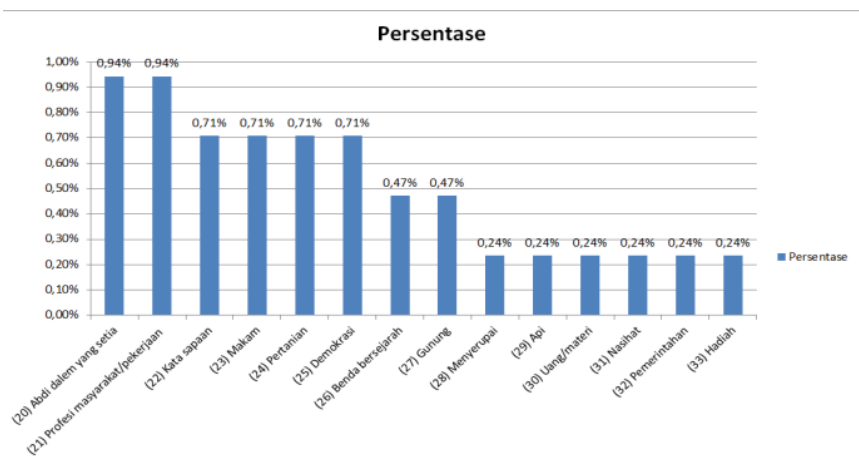

Based on the Bar Chart 3.1.b, there were 13 name sourceorigin forming the classification of Village/Sub-district in Cirebon Regency with the percentage of $<1 \%$, starting from their sources, consisting of (20) Loyal Abdi dalem (0.94\%), (21) people's profession/occupation $(0.94 \%)$, (22) greeting 
words (0.71\%), (23) Tomb (0.71\%), (24) Agriculture (0.71\%), (25) Democracy $(0.71 \%)$, (26) Historical object $(0.41 \%)$, (27) Mountain (0.47\%), (26) Resembling (0.24\%), (29) Fire (0.24\%), (30) Material-Money (0.24\%), (31) Advice (0.24\%), (32) Governance $(0.24 \%)$, and (33) Prize $(0.24 \%)$. These can be presented in Bar Chart (3.1.a) and (3.1.b).

Beside based on the name sources, the village/sub-district toponym presence frequency based on the origin of language forming the place name in Cirebon Regency.

\section{B. Origin of Language in Village/Sub District Toponym in Cirebon Regency}

The origin of language used for naming a place is in the form of lexicon/base word or a combination of lexicons, there is one/more languages, even their combination variation. The toponyms on the names of villages/sub-districts in Cirebon Regency use (1) Cirebon-Javanese (227 regions), (2) Sundanese (17), (3) mixed Sundanese + Cirebon-Javanese (16), (4) combination of Cirebon-Javanese + Indonesian (122), (5) Indonesian (102), (6) Kawi (102), (7) Chinese (20), (8) Sanskrit (40), (9) Arabic (20), (10) combination of Javanese + Sundanese (61), (11) Sundanese + Indonesian (5 regions), (12) mixed Indonesia-Javanese (20 regions), (13) mixed Sanskrit + Cirebon-Javanese (20), (14) combination of Dutch-Sundanese (2), (15) combination of Cirebon-Javanese + Chinese (1), (16) mixed Indonesian-Sundanese (1), (17) mixed Indonesian-Arabic (1), (18) combination of Arabic + Kawi (1), (19) combination of Arab + Sanskrit (1), and (20) Old Sundanese (1) village/subdistrict.

\section{Language Sources Presence Frequency}

Based on the language source-origin presence frequency that formed the toponym in the village/sub-district names in Cirebon Regency, there were 20 criteria of language sourceorigin, as presented in the Bar Chart 3.1.c below.

Chart 3.1.c Language Origin Presence Frequency in the Toponym of Village/sub-district Names in Cirebon Regency

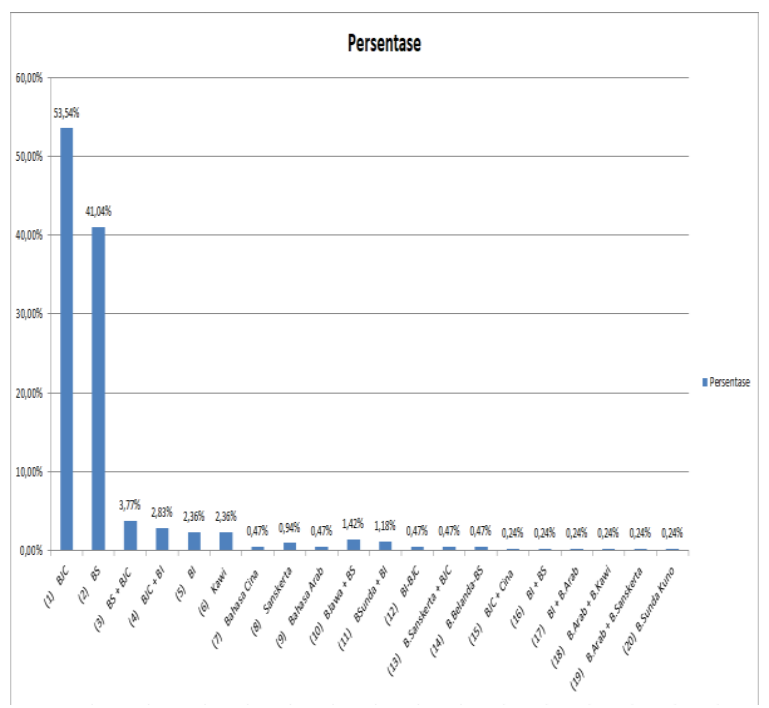

Based on bar chart 3.1.c the toponym source languages presence frequency in the village/sub-district names in Cirebon Regency is derived from (1) Cirebon-Javanese (BJC, the most, of 55.54\%), followed by (2) Sundanese (BS, of $41.04 \%$ ), (3) mixed BS+BJC, of $3.77 \%$, (4) combination of BJC+BI, of $2.83 \%$, (5) BI of $2.36 \%$, (6) Kawi of $2.36 \%$, (7) Chinese of $0.47 \%$, (8) Sanskrit of $0.94 \%$, (9) Arabic of $0.47 \%$, (10) Javanese + Sundanese of 1.42\%, (11) Indonesian-BS of $1.18 \%$, (12) BI+BJC of 0.47\%), (13) Sanskrit BJC of $0.47 \%$ ), and (14) Sanskrit-BJ of $0.47 \%$, (15) combination of CirebonJavanese + Chinese (1) of $0.24 \%$, (16) combination of Indonesian-Sundanese (1) of $0.24 \%$, (17) mixed IndonesianArabic (1) of $0.24 \%$, (18) combination of Arabic + Kawi (1) of $0.24 \%$, (19) mixed Arabic + Sanskrit (1) of $0.24 \%$, and (20) Old Sundanese (1) village/sub-district of $0.24 \%$.

\section{DISCUSSION ON MORPHOLOGICAL ASPECT IN AFFIXATION LINGUAL FORM OF VILLAGE/SUB- DISTRICT TOPONYMS IN CIREBON REGENCY}

The morphological study is one grammatical aspect in language, besides syntactical study (sentence structure). Nida (1957: 1) states that "Morphology is the study of morphemes and their arrangement in forming words". By form (morphologically), the toponym forming practices/processes in the village/sub-district names in Cirebon Regency are in the form of (a) Word, (b) Phrase, (c) Idiom, (d) Affixation, (e) Reduplication, (f) Words Combination, (g) Abbreviation and Acronym, and (h) Onomatopoeia.

In line with Nida, according to Kridalaksana (1996: 28), affixation is a process that changes lexeme into a complex word. In this process, lexeme (1) changes its form, (2) becomes a certain category, thus having category-changed word status, (3) has its meaning changed, more or less. In this process, the base form changes, thus its form changes or is not equal to its final form or the result of formation. Affixation is one of the processes of adding affix into a formation of language unit in village/sub-district name forming with affixed toponyms in Cirebon.

One of the morphological aspects in village/sub-district toponyms in Cirebon Regency (that is currently described) is affixation, besides what is mentioned above. The toponyms in village/sub-district villages in Cirebon Regency based on their affixation process are described below:

\section{Prefixation}

Prefixation means affix put at the beginning of base form. In Indonesian, prefixation is in the form of combining bound morpheme $\{m e-$, ber-, ke-, se-, ter-, pe-per-, and se- $\}$ Kidalaksana, 1996:28). The prefixes are used in the toponym system in village/sub-district names in Cirebon Regency in the form of:

\section{Prefix (ke- and ka-)}

There is Cirebon-Javanese prefix (ke-) in Indonesian that is equal to prefix /ter-/ and the use of prefix $k a$ - from Sundanese 
in village naming in Cirebon Regency. From field and literary data, there are toponyms of village/sub-district names with formation of prefixes $(\mathrm{ke}$-) and $(\mathrm{ka}$-)in the formed toponym, such as Tenjomaya and Kesambi Villages.

The two formed toponyms in the names of Tenjomaya Village and Kesambi Village are presented in table 3.2.1.a below.

Table 3.2.1.a Toponymy of Region with Prefixation $k a$ - and $k e$ -

\begin{tabular}{|c|c|c|c|c|c|}
\hline \multirow{2}{*}{$\begin{array}{c}\text { Basic } \\
\text { Forms }\end{array}$} & \multirow{2}{*}{$\begin{array}{c}\text { Prefix }+ \\
\text { Basic }\end{array}$} & $\begin{array}{c}\text { Combined Process } \\
\text { Morpheme } \\
\text { Supporter }\end{array}$ & $\begin{array}{c}\text { Affixed } \\
\text { Words }\end{array}$ & \multicolumn{2}{|c|}{ Region Name } \\
\hline tenjo & $k a-$ & tenjo & maya & $\begin{array}{c}\text { Katenjo- } \\
\text { maya }\end{array}$ & $\begin{array}{c}\text { Tenjomaya } \\
(\mathrm{ka}-\text { lost })\end{array}$ \\
\hline sambi & $k e-$ & sambi & - & Kesambi & Kesambi \\
\hline
\end{tabular}

\section{(a) Suffixation}

Suffixation is a word forming process where affix is put at the end of base form (Kridalaksana, 1996:29). The process of adding suffix in regional toponym forming process in Cirebon Regency is made by adding suffix $\{-a n\}$ along with allomorph, as can be found in the toponyms below.

\section{Suffix (-an)}

Affixation is a morphological process that produces formed word that changes from its base form. The word formation changes that it is not the same with the final form. The naming of places in Cirebon Regency with word formation derived from adding into bound form at the end of base form is called suffixation. The naming of places in Cirebon Regency show data from suffixation $\{-a n\}$ combined with the base form existing in the toponyms data (1--8), including Getasan, Larangan, Seuseupan, Kepompongan, Bandengan, Klangenan, Gombangan, and Geyongan Villages. Suffix (-an) in Cirebon-Javanese has the allomorph forms $\{-a n\}\{-n\}$, and $\{-n a n\}$. Meanwhile, the allomorphs in place/region naming practice in Cirebon Regency are combination of suffix $\{-a n\}$ with base form in the form of allomorphs $\{-a n\}$ and $\{-n\}$.

\section{(b) Allomorph $\{$-an\}}

Allomorph $\{-a n\}$ is an allomorph form derived from suffix an. Allomorph $\{-a n\}$ will be realized because of base form and base morpheme attached with suffix $\{-a n\}$ with final consonant phoneme. This formation can be found in the following toponyms data.

Table 3.2.1.b Toponymy of Region with Suffixation $\{-a n\}$

\begin{tabular}{|c|c|c|c|}
\hline \multicolumn{2}{|c|}{ Suffixation } & \multicolumn{2}{c|}{ Konfixation } \\
\hline Basic Morpheme & $\begin{array}{c}\text { Bound } \\
\text { Morpheme }\end{array}$ & $\begin{array}{c}\text { Morpheme } \\
\text { Basic+bound }\end{array}$ & $\begin{array}{c}\text { Words of } \\
\text { healing }\end{array}$ \\
\hline $\begin{array}{c}\text { Getas (BJ) 'patah- } \\
\text { patah' }\end{array}$ & $-a n$ & getas + -an & getasan \\
\hline $\begin{array}{c}\text { kepompong (BJ) } \\
\text { 'kepompong' }\end{array}$ & $-a n$ & $\begin{array}{c}\text { kepompong }+ \\
-a n\end{array}$ & $\begin{array}{c}\text { kepompong } \\
-a n\end{array}$ \\
\hline $\begin{array}{c}\text { larang (BJ) } \\
\text { 'melarang' }\end{array}$ & $-a n$ & larang $+-a n$ & larangan \\
\hline
\end{tabular}

\begin{tabular}{|c|c|c|c|}
\hline $\begin{array}{c}\text { geyong (BJ) } \\
\text { 'mengayun' }\end{array}$ & $-a n$ & geyong $+-a n$ & geyongan \\
\hline $\begin{array}{c}\text { seuseup (BS) } \\
\text { 'menghirup' }\end{array}$ & $-a n$ & seuseup $+-a n$ & seuseupan \\
\hline Klangen (BJ) & $-a n$ & klangen $+-a n$ & klangenan \\
\hline $\begin{array}{c}\text { bandeng (BJ) 'ikan } \\
\text { bandeng' }\end{array}$ & $-a n$ & bandeng $+-a n$ & bandengan \\
\hline $\begin{array}{c}\text { gombang (BJ) } \\
\text { 'lubang' }\end{array}$ & $-a n$ & $\begin{array}{c}\text { gombang }+ \\
-a n\end{array}$ & gombangan \\
\hline
\end{tabular}

Sufisk (-an) in Cirebon Javanese has allomorphic forms $\{-a n\}$ $\{-n\}$, and $\{-n a n\}$. Meanwhile, the allomorphs found in the practice of naming places/regions in Cirebon Regency are derived from combining the suffix $\{-$ an $\}$ with the basic form of allomorphs $\{-$ an $\}$ and $\{-n\}$.

\section{(c) Allomorph \{-an\}}

Allomorph $\{-a n\}$ is an allomorph form derived from suffix an. Allomorph $\{-a n\}$ will be realized because of base form and base morpheme attached with suffix $\{-a n\}$ with final consonant phoneme. This formation can be found in the following toponyms data.

(1) Desa Getasan

(3) Desa Seuseupan

(5) Desa Bandengan

(7) Desa Geyongan

The village naming in the formation data (1--8) is derived from base form (getas, larang, seuseup, kepompong, bandeng, gombang, klangen, and geyong) attached with suffix -an in the form of allomorph $\{-a n\}$. The allomorph $\{-a n\}$ is formed because of base form (data 1--8) with final consonant sound. The eight formations forming process can be examined in the pattern below.

Getasan $\quad$ :getas/ $\quad+$ /-an/ $\rightarrow$ getasan

Larangan $\quad:$ /larang/ $\quad+/$-an/ $\rightarrow$ larangan

Seuseupan $\quad: /$ seuseup/ $\quad+/$-an $/ \rightarrow$ seuseupan

Kepompongan : /kepompong/+ /-an/ $\rightarrow$ kepompongan

Bandengan $\quad: /$ bandeng $/ \quad+/$-an $/$ bandengan

Gombangan $\quad:$ /gombang/ $\quad+/$-an $\nrightarrow$ gombangan

Geyongan $\quad:$ /geyong/ $\quad+/$-an $\nrightarrow$ geyongan

Klangenan $:$ /klangen/ $+/$-an $\nrightarrow$ klangenan

The place naming in Cirebon Regency is formed from attachment of suffix /-an/ to base form formed by allomorph $\{-n\}$. This is an allomorph form of suffix $\{-a n\}$. Allomorph $\{-$ $n\}$ is formed since base form or base morpheme is attached with $\{$-an\} ending with vowel and accompanied with assimilation of vowel $/ \mathrm{a} /$ on $\{-\mathrm{an}\}$, thus becoming $\{-n\}$. The assimilation of vowel /a/ has the patterns $/ \mathrm{i}+\mathrm{a} / \rightarrow \mathrm{q} / \mathrm{\varepsilon} \rightarrow \mathrm{u}-\mathrm{u}-\mathrm{a} / \mathrm{\delta} /$, 
$/ \mathrm{o}+\mathrm{a} / \rightarrow / \mathrm{a} /, / \mathrm{a}+\mathrm{a} / \mathrm{a} \rightarrow \mathrm{a} /$, and $/ \mathrm{o}+\mathrm{a}+\mathrm{a} /$. The toponyms in the place names are as follows.

(1) Kampung Kaberan

(2) Desa Kemantren

(3) Desa Kejiwan

(4) Desa Galagamba

(5) Desa Surantaka

The Kaberan Village name in data (1) is derived from Kaberaan, the Kemantren Village name in data (2) is derived from Kemantrian, the Kejiwan Village name in data (3) is derived from Kejiwaan, the Galaamba name in data (4), and Suraantaka Village name (data 5). The naming is derived from name origin or base form added with suffix /-an/ in the form of allomorph $\{-n\}$. Allomorph $\{-n\}$ in data $(1--3)$ is formed since Kaberan, Kemantren, Kejiwan, Galagamba, and Surantaka has base form with vowel /i///a/ and /a/-/a/. Toponym forming in the village names can be examined in the patterns below.

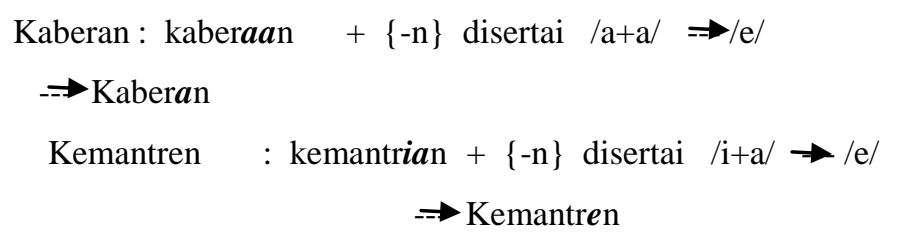

Galagamba : galagaamba $+\{-\mathrm{n}\}$ disertai $/ \mathrm{a}+\mathrm{a} / \mathrm{H} / \mathrm{a}$

$\rightarrow$ Galag $a$ mba

Surantaka

$$
\text { : surantaaka }+\{-\mathrm{n}\} \text { disertai } / \mathrm{a}+\mathrm{a} / \rightarrow \mathrm{a} /
$$

$\rightarrow$ Surantaka

\section{Kaberan}

By form, this village naming is derived from base form beran from affix $k a$ - combined with bera-an, which bears the meaning of tidying up (arranging). Besides, there is another explanation, that the Beran Village's toponym is derived from Beran $=$ kaberan, that bears the meaning of coincidental or from bera, that bears the meaning of cancelling or constant failures. Beran Village has performed governmental order or rule and has a village office, located next to or near Mosque Baitussalam, in front of irrigation gate of Beran Village.

\section{Galagamba}

Galagama is the name of a village located in Ciwaringin District, Cirebon Regency. This village naming by form is derived from Sanskrit, that is a combination of Gala + Amba; Gala means 'hall', and Amba means 'wide', thus Galagamba means a 'wide or big hall'.

\section{Surantaka}

Surakarta is a combination of Sura, bearing the meaning of brave, and taka, derived from antaka, death, thus Surantaka Village means brave to face death.

\section{(d) Confixation}

Confix is affixes put in the beginning and end of base form/base word simultaneously. Confixation is present in the field and literature data as detected in the area naming in Cirebon Regency in the form of confixes ( $k a-a n),(k e--a n)$, (per--an), (pe--an), and (pa--an).

\section{Confix (Ke--an)}

Place naming or toponymy is formed from a combination of confixation (ke--an) in the area names in Cirebon Regency, as present in the following examples.

Kepunduan: pundu $+\{$ ke--an $\} \rightarrow$ kepunduan

$\begin{array}{ll}\text { Kebarepan } & : \text { barep }+\{\text { ke--an }\} \rightarrow \text { kebarepan } \\ \text { Kejiwaan } & : \text { jiwa }+\{\text { ke--an }\} \rightarrow \text { kejiwan }\end{array}$

Kepunduan

By form, the toponym in Kepunduan Village name is derived from the formation of confixation in Sundanese, that is pundung 'leaving a certain place in annoyance' with affixes $k e-a n$. This area becomes the name of Kepunduan Village in Dukupuntang District, Cirebon Regency.

\section{Kebarepan}

Kebarepan is the name of a village located in Plumbon District.The toponym in this village name is derived from the name of a figure in this village's history, that is kebarepan that is derived from confix ( $k e--a n)$ with base word barep 'the one that starts first'. In addition, the of toponymof Kebarepan Village by history and origin of village is based on the event when Ki Agus Mungkad who had defeated Ki Banas Patih in the competition for determining the leader of the area as determined by Sang Aulia Sunan Gunung Jati. He had the right to be the leader in Blok Sikalong with the nickname Ki Bagus Pangaten or Ki Tuan Barep since it was just this time that a leader was chosen by competition. Since this village is the first one (pembarep) established, it was named Kebarepan Village.

\section{Confix (Per--an)}

Place naming or toponym in the area names formed from combination of confix (per--an) in the village/sub-district names in Cirebon Regency can be examined in the following pattern.

Perbutulan: butul $+\{$ per-an $\} \rightarrow$ perbutulan

Pertapaan : tapa $+\{$ per--an $\} \rightarrow$ pertapaan

petapaan 


\begin{abstract}
patapaan $\rightarrow$ 'tempat bertapa’
Perbutulan

By origin, Perbutulan Village naming is derived from formation of (per--an) + base form butul, derived from BJ word butul 'escape'. This is associated with the story in Sunan Gunung Jati era in his battle against the ruler of Galuh Kingdom (Majalengka), during his fierce battle in Lemah Abang region in Perbutulan. The enemy troops were forced to escape and this was indirectly a victory for Cirebon Kingdom.
\end{abstract}

\section{Petapaan Village}

Patapan is the name of a village in Beber District. The toponym in the Patapan Vilage name is derived from the formation of Patapaan 'a place of retreat', derived from BJ base word tapa 'retreat' and affixes (per--an)'showing a place of retreat', forming pertapaan, that changes to petapaan, and changes again to patapaan 'a place of retreat'.

\section{Confix (Pe--an)}

Place naming or toponymy of area formed from a combination of confix (pe--an) in the names of areas in Cirebon Regency can be examined in the following pattern.

$$
\begin{array}{ll}
\text { Pelayangan } & : \text { layang }+\{p e-\text {-an } \rightarrow \text { Pelayangan } \\
\text { Pekalipan } & : \text { kalip }+\{p e-\text {-an }\} \rightarrow \text { Pekalipan } \\
\text { Pekalangan } & : \text { kalang }+\{p e-\text {-an }\} \text { Pekalangan }
\end{array}
$$

\section{Desa Pelayangan(Playangan)}

Bentukan Playangan berdasarkan bentuknya berasal dari kata dasar layang 'melayang' dan imbuhan pe--an 'menunjukkan tempat melayang atau bermain layangan' sehingga berbentuk

\begin{tabular}{|c|c|}
\hline $\begin{array}{r}\text { Pasaleman } \\
\rightarrow \text { Pasaleman }\end{array}$ & $:$ salem (asal dari silem) $+\{p a--a n\}$ \\
\hline Pasalakan & $:$ salak $+\{p a--a n\}$ Pasalakan \\
\hline Pasawahan & $:$ sawah $+\{p a--a n\}$ Pasawaha \\
\hline Pasindangan & $:$ sindang $+p a--a n \longrightarrow$ pasindangan \\
\hline Panoongan & \\
\hline
\end{tabular}
pelayangan, berubah lagi menjadi playangan 'tempat melayang atau terbang'.

Panoongan village naming by form is derived from the formation of toong 'spying' (Sundanese) combined with ( $p a-$ an), becoming Panoongan, finally becoming Panongan, 'a place for spying'. Panoongan Village naming by form is derived from the formation of base form toong 'spying' (Sundanese) combined with ( $p a--a n)$, becoming Panoongan, that is eventually pronounced Panongan, which means a place for spying'.

\section{Pasaleman}

Pasaleman Village naming by form is derived from Sundanese, that is from the formation of ( $p a--a n)^{\text {'affixes that }}$ show a place when combined with base form' that is combine with base word/word of origin silem 'disappear' of which pronunciation changes from Pasileman to Pasaleman, which means village name based on the event silem 'disappearance of magic headed snake'.

\section{Pasalakan}

Pasalakan Village naming is derived from Sundanese, formation of confix ( $p a--a n)$ combined with base form salak, forming Pasalakan.

Confix (Ka--an)

Place naming or toponymy or area formed from combination of confix ( $k a--a n)$ in the area names in Cirebon Regency and City can be examined in the following pattern.

Kapetakan $:$ petak $+\{$ pe--an $) \rightarrow$ Kapetakan

\section{Kapetakan}

Kapetakan Village naming by form is derived from the formation of Petak (personal name of prince Petak, from Bani Israil) combined with confix $(k a--a n)$, which means the place derived from the name of Prince Petak or name of place based on the event related to Prince Petak.

Based on field and literature data, the toponyms in the village/sub-district names in Cirebon Regency by morphological process are derived from affixation, in the form of (a) Prefixation, affixation in the beginning of base form; (b) Suffixation, suffixation in the end of base form; and (c) Confixation, combination of two affixes \{affix-suffix simultaneously added to base form $\}$. The toponyms by morphological process from affixation elements in the village/sub-district names in Cirebon Regency are entirely 37 names of villages/sub-districts.

\subsection{Philosophical Meaning Reconstruction}

\subsubsection{Relationship between Human and Creator (God Almighty)}

The toponym in Cirebon may become one of the ideological indicators of a group of society covering the values followed (good/bad or appropriate/inappropriate), beliefs and expectation that the name given will conform to the society's demand when it is made and/or after the period after the name has been given. The relationship between human and Creator is reflected in the naming practice of villages in Cirebon Regency, such as the names of (1) Kalideres Village, (2) Kalimaro Village, (3) Kaliwulu Vilalge, and (4) Cisampih Village. The toponym of the village names contains the philosophy of Oneness of God Almighty and religious values. 


\section{Kalimaro}

Kalimaro Village's naming based on its form is derived from the words "Kalimah Loro" which may be defined as two sentences of shahada. The naming of Kalimaro has the philosophy that as creation, it is a must for Muslim to remember the Oneness of Allah SWT. as the Creator and Prophet Muhammad Saw. as Allah SWT's Messenger. Thus, the toponym of the naming of Kalimaro aims at reminding its entire people to firmly hold the two sentences of shahada.

\section{Kaliwulu}

Kaliwulu is the name of a village located in Plered Subdistrict. By form, the naming of Kaliwulu Village is derived from Javanese language, which is a combination of two forms of word, namely noun base word Kali from Cirebon Javanese (KBCI, 2007: 208) 'river' and verb base word wulu from Sundanese language which initially absorbs the word wudlu 'clean body parts before performing salat' (source from KBS, 2006:745), thus the word wulu (BS) is derived from Arabic word. Therefore, the naming of Kaliwulu Village is etymology derived from $\mathrm{BJC}$ and $\mathrm{BA}$, which is the word wulu which is a change in pronunciation from wudhu (BA).

\section{Kalideres}

The naming of Kalideres Village contains philosophical meaning that all humans must believe, fathom and practice the teachings contained in two sentences of shahada and AlQuran. This philosophy is derived from the words of Nyi Mas Ratu Rara Mangi who believes that if one wants to achieve true happiness in his life, he must always recite/learn/study two things, namely worldly and ukhrowi (afterlife) matters, physically and spiritually. The two must be balanced so that humans will have and master science and technology and faith and devotion.

\section{Cisampih}

The naming of Sampih contains the philosophy of togetherness and mutual assistance in improving the environment, and of noble mental attitude. Besides, with humility, we should be aware that any success we gain is merely under the grace of Allah SWT. They prostrate, pray, adore and praise God's greatness. The place where they praise and worship God is then named Kampung Pamijen.

The word Sampih is derived from Sundanese language, consisting of $\mathrm{Sa}$ - and Ampih. Sa-bears the same meaning with $\mathrm{Se}$ - or one and Ampih bears the same meaning with simpan or rawat, thus the meaning of Sampih is an area which keeps its inhabitants until they get used to it (Kerasan). In Cisampih, there is clear water flowing from a spring, which contains the philosophy of noble mental attitude.

Water flows to a lower place, which means that Sampih villagers must be humble, give and support those of lower level, thus Sampih villagers must support and help those weaker.
Water has the characteristics of equality to its peers, thus in socialization, Sampih villagers must not discriminate anyone and avoid arrogance and nobility; they are equal one to another. Clear water is an illustration of holy and pure life. This means that Sampih villagers always have holy heart, mind, words and acts in their daily life. Water from spring reminds them not to forget people's merit, parents we pay respect to and youngsters we love.

\subsubsection{Relationship among Humans}

There is relationship between human and human integrated with interpersonal, inter-ethnic and inter-cultural and even inter-countries connection in the community of Cirebon Regency, which is realized in the practice of naming of villages in Cirebon Regency. This may be found in the following names: (1) Jamblang, (2) Kalianyar, (3) Kaligawe, and (4) Gumulung Lebak.

\section{(a) Philosophy of Keeping Harmony in Inter-ethnic Life}

\section{Jamblang Village}

The philosophy of harmonious social multi-ethnic life may be found in the naming of Jamblang Village. Jamblang is a village in Jamblang Subdistrict, Cirebon Regency. This village is known as the oldest Chinatown Village in Cirebon, since Chinese people have long resided in this village, and some also state that Jamblang Village was established by Chinese people. Among the legacy of Chinese people in this village is Jamblang Temple, which is believed to be hundreds of years old. In addition, this village is also known for its culinary delight, Nasi Jamblang, which is the trademark of Jambang people.

Intercultural relationship has long been established between Chinese people and local people of Cirebon Regency, both in trade and zone or area relationships. It is expected that the very existence of Chinese people in Cirebon may actually be traced from the history of interaction between Chinese people with local people (people of Cirebon) which took place before the arrival of Dutch colony into Indonesia.

The culture of Cirebon palace influences the course of the community or people in Jamblang. This is related to the history and naming practice of the area which is later called Jamblang Village, in which Jamblang Village was chronologically established by a Chinese person named Babah Chong An at the time of Cirebon Sultanate under leadership of Sunan Gunung Jati.

According to local tale, Baba Chong An lived at the time of Sunan Gunung Jati since it is explained that Baba Chong An's daughter named Liong Sie Tin married Raden Banjar Pantoman, who was an apprentice of Sunan Gunung Jati. It is also told that the establishment of the Temple in Jamblang was under approval of Sunan Gunung Jati. 


\section{(b) Philosophy of Mutual Aid and Hard Work}

\section{Kalianyar Village}

The philosophy of mutual aid and love to leader is the meaning and philosophy of hydronym of the name of Kalianyar Village. The naming of Kalianyar is derived from the behavior and relationship between humans among the people in the area visited by Raden Ngampabaya who won a fight with Ki Sena. The people of Kampung Karang Jekeng immediately welcomed their winning hero with pride and happiness while shouting "Tiyang kalih anyar pinanggih" repeatedly. That the origin of the name of Kalianyar Village is from the people's words/shouting, and their words were later only heard "... kali anyar...", which is shorter with the name of Kalianyar Village, which bears the meaning of a village of people's pride which was first visited by Raden Ngampabaya who won a fight with Ki Sena.

\section{(c) Philosophy of Hard Work}

\section{Kaligawe Village}

Hard work and mutual aid are the meaning and philosopy of toponym of the name of Kaligawe village. Kaligawe Village is initially Randegan Village 'stoppage/rest area' since many refugees from Cirebon and Gebang stopped at Kaligawe Villaage for a rest (ngarandeg 'take rest'). In their rest, the refugees had a look at the area where they take a rest. They agreed to open the area, establish a settlement, and the area was cleared to establish a settlement.

After clearing the area and establishing the settlement, the village was named Randegan Village, which means 'stoppage/rest area' village. Later, they stayed and made Kali which was named Cibedug since it was constructed until noon (beduk dzuhur). After the kali was finished, the name of Randegan Village was changed to Kaligawe Village (since the river (kali) for irrigation was made by local people) and the name Kaligawe is derived from the word kali 'river' which was made by local people (mutual aid).

\section{(4) Philosophy of Democracy}

\section{Gumulung Lebak Village}

The naming of this village is based on the philosophy of social life values covering democracy and consensus values to harmoniously reach an agreement in social life. Humanhuman relationship in the cultural constellation is based on democratic and consensus values in social life. This is apparent in the naming of Gumulung Lebak Village, which by form is derived from the combination of two forms of words, Gumulung and Lebak. The word Gumulung is derived from abbreviated form of Gum from the word Gum (Dutch language), which means 'agree' and ulung which means 'noblest/most excellent people'. This shows that this naming is derived from the name of place where discussion made by the santri took place to make a decision through deliberation.

\subsubsection{Human-Nature Relationship}

By characteristics, the people of Cirebon Regency are socially classified as dominantly coastal people although some are agricultural people and traders. Sociologically, the characteristics of coastal people are different from agricultural people due to difference in the characteristics of resources they face. The condition of risky resources causes fishermen to be strict, decisive and open.

This may be observed from the practice of place naming in the toponym of villages in Cirebon Regency. The characteristics of coastal people in the toponym or naming of place/geography covering villages in Cirebon Regency are mostly related to maritime matters or aspects, for example, the names of Kalisapu, Kalianyar, Kalimaro and Kaligawe villages.

Etymologically, Kalisapu Village consists of two words, namely kali and sapu. In Kamus Besar Cerbon-Indonesia (2007: 208), kali means 'river' and sapu means 'coconut leaf stick broom' (KBCI, 2007: 276). By naming history, Kalisapu Village was given by Sunan Gunung Jati to Nyai Khalimah (a descendant of noble from Champa, with pretty face, wife of H. Mansur (younger brother of Prince Cakrabuana) who had helped Sunan Gunung Jati develop Islam in Cirebon. The background of naming of Kalisapu is that there was a river circling the north of Mount Jati and Mount Sembung. The river extended from west to east towards Java Sea and was the main way towards Pakungwati Palace. The flow of the river was called Condong River. Therefore, the naming of Kalisapu village is related to historical factor and natural condition at that time.

\section{Tuk Village}

The naming of Tuk village is derived from (1) the event when Haji Mancur thrust his stick into the ground as per Godly guidance, leading to rapid flowing of water from the Tuk 'spring' and (2) as a token of respect to Nyai Gedeng Tuk. According to the history orally told by the people in Cirebon, the name of Tuk Village is derived from the name of a female figure named Nyai Gedeng Tuk who was in the area when the spring was found and captivated Haji Mancur's heart (at that time he was assigned by Sunan Gunung Jati to find a source of water). After praying to God Almighty, Haji Mancur thrust his stick into the ground. With God's blessing, in the ground where Haji Mancur's stick was thrust there was water flowing out rapidly from Tuk 'spring', thus all wells around it were filled with water.

The naming in Cirebon Regency is often made based on the existence of flowing water and how water flows, such the name of Tukmudal and Sumber Villages. For example, by origin Tukmudal Village consists of two words, namely tuk and mudal. In Javanese-Cirebon language, tuk means 'spring, source of water, water flowing continuously' (KBC, 2005: 335 ) and mudal means 'cloudy water, coming out (from its measure or source)' (KBCI, 2007: 266), thus Tukmudal 
Village means 'a village where there is cloudy water which flows continuously'.

\section{Rawagatel Village}

The practice of naming of Rawagatel Village gives us an overview of harmonious relationship between human and the universe, especially in maintaining humans' attitude of natural preservation where they live and have social life, such as by maintaining the cleanliness and purity of pool water as drinking facility and preserving healthy and clean environment. Therefore, the philosophy of naming of Rawagatel Village is people living in social community must maintain their heart and physiology clean so as to be free from spiritual diseases, such as envy, jealousy and wrongdoing.

Rawagatel is the name of a villge in Arjawinangun Subdistrict. According to the folklore in the area, the naming of Rawagatel Village is derived from a supranatural phenomenon, which is the formation of a pool or balong which brings disaster to humans. This balong was formed from a fight between cemeti (manifestation of Jakatawa) and black smoke (manifestation of Ki Pacacahan). The cemeti fell into the pool. The place where the cemeti fell is called Rawagatel. Therefore, the toponym of the name of Rawagatel Village by formation is derived from the combination of two words, rawa from Javanese 'pool' and gatel (Javanese) 'itchy' thus Rawagatel means a pool which causes itch.

\section{Gagasari}

The philosophy of toponym of Gagasari Village is related to balance and maintenance between humans and the nature. The beauty of Gagasari Village may be viewed from its wellmaintained environment. The beauty of surrounding nature truly captivates our eyes. Besides the well-maintained beauty of the nature, its people's hospitality values still exist.

The naming of Gagasari Village by formation is from two words, Gagaan 'paddy plant' and sari 'essence'. In combination, the two words mean a village which has or is decorated by beautiful fertile paddy plants.

\section{Ciwaringin Village}

The philosophy of toponym of Ciwaringin is the growing power and struggle power to survive persistently, as strong and shady as ficus tree. Life should protect family or loved ones (like how shady ficus tree, where people may take shelter).

Ciwaringin is a village located in Ciwaringin Subdistrict, Cirebon Regency. This area was, before becoming a village, a sub-village developed by Tubagus Ismail. Its naming was derived from the word Ciwaringin (Sundanese and JavaneseCirebon languages), from the word $\mathrm{Ci}$ - Sundanese language which means 'water in the river' and the word waringin/bringin/wringin (in Javanese language) in the end of road there is a 'high, big and shady ficus tree'.

\subsubsection{Human-Magic Relationship}

Many immigrants came with their cultures, such as India with their Hinduism and Buddhism and Arabs with Islam. In the period before Islam came, the culture along the coast was filled with Hindu culture brought from India. This led to forms of worshipping and tradition of cult of spirits as the manifestation of their obedience to the nature.

Before Hindu culture came, the people around Cirebon worshipped any surrounding natural manifestations. They believed that nature had its own spirit, which was always present, observe and maintain their life (Cerbon, 1982:18). The belief of majority of the people before Hindu was animism and all forms of arts became the media of communication with spirits, including form, element or decoration used, all of which have spiritual symbolization and religious meaning.

The relationship between human and magic, including magic realm in $\mathrm{v}$ illage naming practice in Cirebon Regency is reflected in the toponym of Bringin Village below.

\section{(a) Philosophy of Life Struggle}

\section{Bringin Village}

The naming of Bringin Village in Cirebon Reency has meaning and philosophy referring to survival and glory of the people in that area. Beringin (ficus tree) is the life of life or glory. Bringin is the name of a village located in Ciwaringin Subdistrict.

The naming of Bringin Village is, by form, derived from the word Bringin which means 'ficus tree' and from the name of a figure who first visit that place, namely Ki Gede Bringin. It is said, after the end of Kedongdong War, $40 \mathrm{Ki}$ Gede who participated in the war was going to their respective own home. On the way home, they rested. They take shelter under a shady bringin 'ficus' tree. Because of exhaustion, they fell asleep soundly. When they woke up, a mysterious voice said that one who came to the place was called Ki Gede Bringin. The one first came to that place was Ki Gede Srangin, who was later known as Ki Gede Bringin.

\section{CONCLUSION}

The acculturation, assimilation, cultural, and historical processes, the utilization of its language contained in the regional naming in Cirebon Regency have resulted in its unique and typical characteristics in the practice of naming its areas, especially the naming arrangement for village/subdistrict areas in Cirebon Regency.

Toponyms in the names of villages/kelurahan in Cirebon Regency represent the lifestyle and collectivity of the memory of their owners. The use of language in the study of toponyms on the names of villages/kelurahan in Cirebon Regency is used to maintain and preserve the ancestral past culture (intangible cultural heritage), such as philosophical values (local wisdom), historical, geographical, economic, political, 
cultural and linguistic ecology. Based on the results of toponym research, the names of villages/boroughs in Cirebon Regency are classified into two, namely (a) Source of name and (b) Origin of language.

Based on data in the field based on the source name toponymy (1) Wind direction 129 villages $(30.42 \%)$; (2) water element and maritime affairs 94 villages (22.17\%), (3) figures 74 villages (17.45\%); (4) Flora 68 villages (16.04\%); and others so that they are the focus of toponymy studies. Based on the origin of the language, there are 10 languages used in naming regional locations in Cirebon Regency, namely (1) Cirebon Javanese, 227 villages/borough, (2) Sundanese, 174 villages/borough, (3) Sundanese + Javanese, 16 villages, (4) Java Cirebon + Indonesia, 12 villages, (5) Indonesian, 10 villages, (6) Kawi, 10 villages, (7) Sanskrit, 4 villages, (8) Chinese, 2 villages, (9) Javanese + Sundanese, 6 villages, (10) Arabic, 2 villages, and others.

The morphological aspects of toponym affixation of village/borough names in Cirebon Regency are focused on (a) Prefixation, the initial affixation of the basic form; (b) Sufixation, affixing at the end of the basic form; and (c) Confixation, the joining of two affixes $\{$ a prefix-suffix together or simultaneously in the base form $\}$. Affixation in the toponymy of village/sub-district names in Cirebon Regency is in the forms of (1) Prefix (ke- and ka-), (2) Suffix (-an), and (3) Confix (ke--an), (per--an), (Pa--an), and (ka--an). Furthermore, those village and sub-district names in Cirebon Regency represented the conditions of egalitarian communities living in the costal-maritime areas to the socialhistorical-cultural-religious changes by having meaning and philosophical representations: (1) relationship between humans and God (the Almighty), such as the philosophy on the belief of One Supreme God; (2) relationship of humans with the other humans, such as the philosophy in maintaining the harmony of life between ethnics, nationalism, communal work (gotong-royong) and hard work, life struggle; (3) relationship between humans and the surrounding nature, thus the harmony and mutual relationship which were perfectly intertwined between the natural environment and language influenced the hydronyms on the village and sub-district names in the related areas.

\section{REFERENCES}

[1] Alwi, H., Dardjowidjojo, S., Lapoliwa, H., \& Moeliono, A. M. (2003). Tata bahasa baku bahasa Indonesia.

[2] Anshari, B. I., Dede, M., Tirtayasa, R., \& Musthafa, K. (2017). Kajian Etnosemantik Dalam Toponimi Wilayah Kabupaten Dan Kota Cirebon. Teknologi Bahasa Dan Budaya Dalam Penelitian Leksikologi Dan Leksikografi, 64--69.

[3] Ayanovna, N. L. (2014). The Role of Old Turkic Place Names in Teaching History. Procedia - Social and Behavioral Sciences, 141, 1054-1061. https://doi.org/10.1016/j.sbspro.2014.05.177
[4] Brown, B. (1947). Studies in Linguistics Relativity. In E. E. et al Maccoby (Ed.), Headings in Social Psychology. Hold Rinehart and Winston.

[5] Camalia, M. (2015). Toponimi Kabupaten Lamongan (Kajian Antropologi Linguistik). PAROLE: Journal of Linguistics and Education, 5(1), 74-83.

[6] Chaer, A. (2008). Morfologi bahasa indonesia: Pendekatan Proses. Rineka Cipta.

[7] Darheni, N. (2018). Regional Toponymy in Cirebon Regency: An Ethnolinguistic Study.

[8] Hall, S. (1997). Representation: Cultural representations and signifying practices (Vol. 2). Sage.

[9] Hertley, J. (2010). Communication, cultural and media studies: konsep kunci. Jalasutra.

[10] Hough, C. (2016). The Oxford Handbook of Names and Naming. Oxford University Press.

[11] Kostanski, L. (2009). "What's in a name?": place and toponymic attachment, identity and dependence: a case study of the Grampians (Gariwerd) National Park name restoration process. Dissertation, March.

[12] Kridalaksana, H. (1996). Pembentukan kata dalam bahasa Indonesia. Gramedia.

[13] Lauder, A. F., \& R.M.T.Lauder, M. (2009). Berbagai kajian linguistik. Pesona Bahasa, 220-248.

[14] Muntele, I. (2018). Hydronymy and its geographical relevance in historical Moldavia. Diacronia. https://doi.org/10.17684/i8a119en

[15] Nida, E. A. (1957). Morphology; the Descriptive Analysis of Words. University Press.

[16] Ogden, C. K., \& Richards, I. A. (1923). The meaning of meaning: A study of the influence of thought and of the science of symbolism.

[17] Prihadi. (2015). The Cultural Background of Toponim System of Hamlets/Villages in Yogyakarta Special Province (An Antropolinguistic Study). Research on Humanities and Social Sciences, 5(6).

[18] R.M.T.Lauder, M. (2013). "Peran Toponimi dalam Pelestarian Budaya dan Pembentukan Jati Diri Bangsa." Seminar Nasional Toponim, 9-18.

[19] Ramlan, L. (2008). Tayub cirebonan: artefak budaya masyarakat priyayi. Sunan Ambu Press.

[20] Ruspandi, J., \& Mulyadi, A. (2014). Fenomena Geografis di Balik Makna Toponimi di Kota Cirebon. Jurnal Gea, 14(23).

[21] Sadiyana, S., \& Pariwisata, J. B. (Indonesia). D. K. dan. (2007). Kamus bahasa Cerbon-Indonesia. Disbudpar Prov. Jawa Barat. https://books.google.co.id/books?id=F-XDcQAACAAJ

[22] Salzman, Z. (1990). Toponymy of the Bigar Region in the Romanian Barat. Anthropological Linguistics, 32(12), 139-148.

[23] Spradley, J. P. (2013a). The Ethnographic Interview. Tiara Wacana Yogya.

[24] Spradley, J. P. (2013b). The Ethnographic Interview (M. Z. Elizabeth (trans.)). Tiara Wacana Yogya.

[25] Stanberg, S. (2016). River Namesi. In C. Hough (Ed.), The Oxford Handbook of Names and Naming.

[26] Sudaryanto. (2015). Metode dan Aneka Teknik Analisis Bahasa: Pengantar Penelitian Wahana Kebudayaan Secara Linguistis. Sanata Dharma University Press.

[27] Sudjana, T. D. (2005). Kamus bahasa Cirebon. Humaniora Utama Press. https://books.google.co.id/books?id=papkAAAAMAAJ

[28] Taylor, S. (2016). Methodologies in Place-name Research. In The Oxford Handbook of Names and Naming.

[29] Van Langendonck, W., \& Van de Velde, M. (2016). Names and Grammar. In The Oxford handbook of names and naming.

[30] Wahidin. (2006). Metode Pendidikan Ilmu Pengetahuan Alam. Sangga Buana. 